\title{
Multilingualism in Greece: A Study of Speech Production of Trilingual Children
}

\author{
Fotini Anastassiou and Georgia Andreou \\ University of Thessaly \\ fanastassiou@gmail.com, andreou@uth.gr
}

\begin{abstract}
During the last twenty years Albanian immigrants have come to Greece and they have formed a large community in different parts of our country. Their children now are of the second generation and they go to Greek state schools, being taught according to the official syllabus in the same classes as Greek students. We will present a study on the vocabulary interaction amongst the three languages of fifty trilingual children. Our hypothesis is that trilingual children will seek help from their L1 (either Greek or Albanian) while speaking their L3 (English). Furthermore, we will investigate cross- linguistic influence: a) Interactional strategies and b) Transfer lapses as previously described by Cenoz (2001). Since multilinguals have the ability to activate several languages at the same time, cross-linguistic influence in speech production has been a popular field within the studies on multilingual lexicon, since according to Cenoz (2001) the way a person's languages interact with each other can help us comprehend the multilingual and the mental lexicon.
\end{abstract}

\section{Introduction}

Many attempts have been made so far to approach a definition of trilingualism. Most researchers have attempted to define trilingualism through bilingualism and trilingualism has sometimes been regarded as a branch of bilingualism or even as an extension of bilingualism. Haugen refers to multilingualism as "a kind of multiple bilingualism" (1956: 9). Oksaar defines bilingualism as "the ability of a person to use here and now two or more languages as a means of communication in most situations and to switch from one language to the other if necessary" (1983: 19), whereas Skutnabb-Kangas (1984) suggests that more than two languages can be present in the person she defines as bilingual.

\section{(cc) BY-NC-ND}


Cenoz and Genesee (1998) suggest that a student should be defined as trilingual if $s /$ he can use her/his three languages to communicate in both oral and written speech. Furthermore, they describe multilingualism as the final result of the process of acquisition of several non- native languages. Moreover, since many scholars have proposed that learning an $L 3$ is a different process than learning an L2, Hufeisen (1998) suggested that multilingualism should be used to refer to the learning of more than two languages. According to Herdina and Jessner (2000), multilingualism is to be considered as a varied phenomenon involving bilingualism and monolingualism as possible forms, but addressing mainly those languages learned after a second one, so, therefore, bilingualism cannot be identified with multilingualism.

\section{Speech Production and Trilinguals}

Lambert (1990) gives us his working hypothesis on the speech production of trilinguals. "Bilingualism provides a person with a comparative, three-dimensional insight into language, a type of stereolinguistic optic on communication that the monolingual rarely experiences" (1990: 212). We could assume that if a bilingual possesses the qualities that Lambert (1990) hypothesizes then a trilingual would possess the same and even more. Lambert (1990) goes on to propose that bilinguals have a certain ability to switch codes when referring to speakers of either language (L1 or L2) or even when communicating with bilingual speakers that speak the same languages, especially in diglossic speech communities. If that is the case with bilinguals, we could then hypothesize that a consecutive trilingual who went through a bilingual period and then proceeded to the trilingual period has built up his/her language facilities and can switch codes in a more rapid and effective way.

Jessner (1999) also points to the advantage of bilinguals over monolinguals regarding their interactional competence, that is, their ability to communicate with others, to perform and interpret communicative actions on the basis of the sociocultural and sociolinguistic norms of a particular speech community. In fact, as argued by Jessner (1999), bilinguals might show a higher degree of pragmatic development than monolingual speakers. We suggest that, by extension, Jessner's approach may apply to trilinguals too.

According to Cenoz (2001), language production and perception are more complex when more than two languages are involved. Speech production in the different languages a multilingual uses may share most of the general characteristics of speech production in monolinguals and bilinguals but is bound to me more complex and may be linked with characteristics which are the outcome of the interaction between different linguistic systems (Cenoz, 2001). According to Grosjean (2001), when bilinguals are in monolingual mode their other language is deactivated to a great extent and their language production 
resembles that of monolinguals. Both languages are activated when they are in bilingual mode, which is when their speech production indicates characteristics of bilingual speech, such as borrowing and code switching. Hoffmann \& Stavans (2007) propose that Grosjean's model could be used in trilingual speech production too; hence, trilinguals would then be able to operate in monolingual, bilingual and multilingual modes according to the degree of activation or deactivation of their three linguistic systems.

"The study of child trilingualism can be frustrating as it is often hampered by practical problems relating to the collection and interpretation of data on the one hand, and the absence of theoretical models that might be used for comparison on the other. The rewarding feature of such endeavours, however, is that they do allow fascinating glimpses into the human capacity of processing language and the linguistic resourcefulness of multilinguals" (Hoffmann \& Stavans, 2007: 55).

Moreover, Hoffmann and Stavans (2007) point out that most of the research on trilingualism focuses on individuals who acquire or learn a third language in a school context (Cenoz \& Genesee, 1998; Cenoz, Hufeisen, \& Jessner, 2001) or immigrant minorities who learn a third language in social contexts (Baetens-Beardsmore, 1993). Also, the majority of these studies look into the development of a third language consecutively to the development of one or two other languages, just like our study presented below.

The aim of the present study was to investigate the vocabulary interaction of the three languages of bilingual primary school children who are learning their L3. Specifically, this study aimed to explore cross- linguistic influence as far as interactional strategies and transfer lapses are concerned, as previously described by Cenoz (2001). Our hypothesis was that trilingual children would use their L1 (either Greek or Albanian) as the source language or default supplier of cross-linguistic influence, while speaking their L3 English.

\section{Methodology}

\subsection{Participants}

Our participants were 50 bilingual children, whose L1 and L2 were either Greek or Albanian and who were learning their L3. All of the children came from an immigrant background and were selected according to their bilingualism and their level in their L3, English. More particularly, participants were all "A1 level" learners 
of English that their L1 and L2 were either Greek or Albanian. In order to define the participants' level in English ( $L 3$ ) they were asked to narrate two picture stories. According to their produced "text" their level in English was then estimated "A1" according to the Common European Framework of Reference for Languages.

The participants' ages ranged between 9 and 12 years old and their mean age was 10 years and 7 months. Their three languages were Albanian and Greek (L1 or L2) and English (L3). Our sample consisted of 26 girls and 24 boys. All of them were children of Albanian immigrants and they were born in Greece. First of all, we collected data regarding our learners through questionnaires. The aim of this questionnaire was to elicit demographic data about the participants (age, sex, class they attended), as well as information on their three languages (which one were their L1 and their L2 and the years they had been using their languages, how many years they had been learning their L3). On the basis of the data, two groups of participants were formed:

Group 1: this included 23 children (14 girls and 9 boys) who had as their $L 1$ Albanian, L2 Greek and L3 English.

Group 2: this included 27 children (12 girls and 15 boys) who had as their $L 1$ Greek, L2 Albanian and L3 English.

Regarding Group 2 the children's parents explained that they had decided to speak to their children in Greek, even though their level of Greek might not have been so high at the time, because they believed, this might help their children adapt more easily to Greek society. This is probably a common strategy immigrants follow with their children.

\subsection{Instruments}

We followed Cenoz's (2001) method which aimed to investigate trilingual children's speech production and specifically cross- linguistic influence. Cenoz provided the bilingual participants with two wordless picture stories (one taken from their English language school text book that they had already been taught and another one they had not seen before). She asked the children to narrate the two stories in their L3 (English) that they were learning at school. Her participants were also divided in two groups according to their $L 1$ and finally their interactional strategies and transfer lapses were identified for each one of the two groups.

We too used the same wordless story book with Cenoz: "The boy, the dog and the frog" by Mercer Mayer (1969). This is a commonly used series of story books for language studies ("Story 1" from now on). We also asked children to narrate a wordless picture story taken from their English school book "Sail away 2" ("Story 2 " from now on). Before the children started narrating they were told that they 
could draw on and use whichever language they wanted while narrating in their L3. Specifically, they were told: "the languages you speak are all yours, you can use them if you feel you need to".

Our aim was to identify the language ( $\mathrm{L} 1$ or L2) that the participants would use every time they needed help while narrating in their $L 3$. We considered two types of cross- linguistic influence, following Cenoz (2001): "Interactional strategies which are intentional switches into languages other than the target language and their presence will depend on language mode so that their frequency is related to the bilingual and monolingual mode adopted by the speaker. Transfer lapses that are non-intentional switches and are not preceded by a pause or false start and can be regarded as automatic" (2001: 107). All interviews were audiotaped and transcribed and all cases of cross-linguistic influence were identified. We also used a bilingual interpreter (Greek, Albanian) to help us with the context of the Albanian transfer lapses.

\section{Results}

The narrations of the participants were transcribed and analyzed and the cases of interaction with the interlocutor as well as the cases of transfer lapses were identified. For each one of the two groups that were formed according to their L1, interactional strategies and transfer lapses were identified and analyzed for both stories that were narrated.

\section{Group 1}

Interactional strategies

Story 1:

The main language that the children of Group 1 used to narrate Story 1 was their target language, L3, English. However, when seeking for help from their interlocutor all of the learners of Group 1 would use Greek, their L2. Examples:

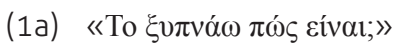

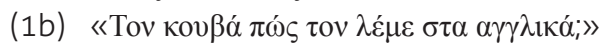

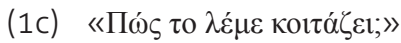

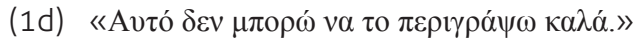

Story 2:

Children of Group 1 were found to use the same interactional strategy that they used while narrating Story 1 when they narrated Story 2. So, during their narrations in their L3, children of Group 1 would ask for help from their interlocutor in Greek again. Examples: 


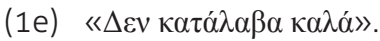

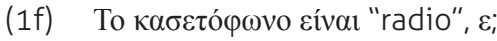

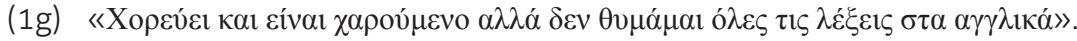

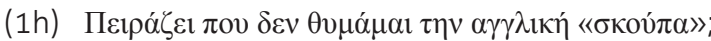

\section{Transfer lapses}

While children were narrating in their target language L3, as they were requested to do, transfer lapses were found. Story 1 was the one that children had not seen before and transfer lapses in their L1, Albanian were a small percentage out of the total utterances produced. However, there was a higher percentage of intrasentential code switching in their $\mathrm{L} 2$.

Story 1:

In a total of 638 utterances, 124 (19,5\%) were transfer lapses from their L1 Albanian. Examples:

(2a) They go to the tekpem (lake) to catch the frog.

(2b) They try to catch a bretkoca (frog).

However, when these children code switched to L1 while narrating in L3, in $80,5 \%$ of the utterances they automatically continued their sentence in $\mathrm{L} 2$. Examples:

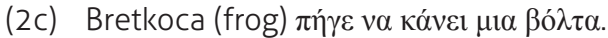

(2d) Tsuni (child) $\pi \eta ́ \gamma \varepsilon \beta$ ßó $\lambda \tau \alpha$.

Story 2:

While children narrated Story 2 which they had previously worked with in class, transfer lapses were found in their L1, Albanian. These lapses were more in comparison with Story 1 . However, the intrasentential code switching to L2 that was found in a high rate in Story 1 was not found in Story 2 at all.

In a total of 285 utterances, 114 (40\%) were transfer lapses from their L1 Albanian while speaking their L3. Examples:

(3a) Then he piu (drinks) milk.

(3b) He pastron (cleans up).

(3c) His mom wants him to go heret (early) to school.

(3d) He picks up his canta e shkolles (school bag) and leaves.

With respect to the second group, that their L1 was Greek, the types of crosslinguistic influence used are as follows: 


\section{Group 2}

Interactional strategies

During their narrations children of Group 2 used their L1, Greek, every time they would ask for help from their interlocutor in both Story 1 and Story 2. Examples:

Story 1:

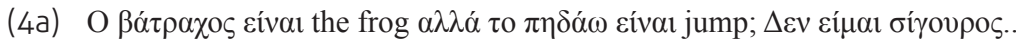

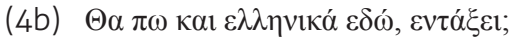

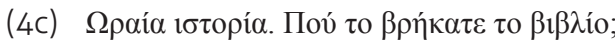

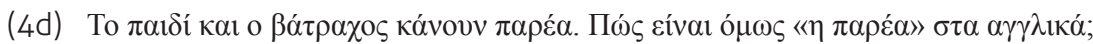

Story 2:

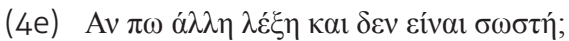

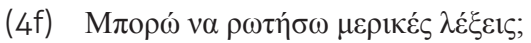

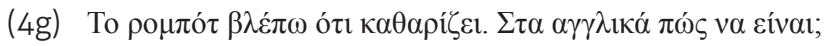

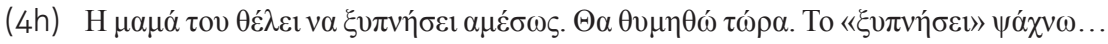

\section{Transfer lapses}

Children of Group 2 that their L1 was Greek, were found to be transferring from Greek. Differences were observed in the rate of transfer lapses in Story 1 and Story 2. Specifically, there were more transfer lapses in Story 1 (that children had not seen before) than in Story 2 (that they had already been taught in class).

Story 1:

In a total of 459 utterances 319 (70\%) were transfer lapses from their L1 Greek. Examples:

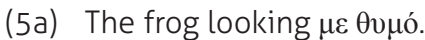

(5b) The boy wants $v \alpha \pi$ ió $\sigma \varepsilon 1$ the frog.

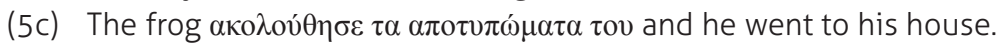

(5d) He saw the dog and the frog $v \alpha \pi \lambda \varepsilon v o ́ v \tau o v \sigma \alpha v$.

Story 2:

In a total of 158 utterances, 97 (61,40\%) were transfer lapses from their L1 Greek. Examples:

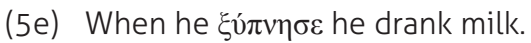

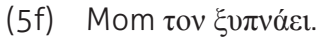

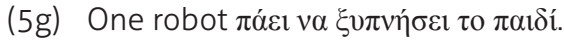

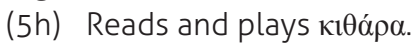




\section{Discussion}

The data presented above indicated that children transferred from their $L 1$, either Greek or Albanian, while they were narrating in their L3, English. This was in line with our hypothesis that participants would use their L1. We found out that in both groups there was more cross- linguistic transfer while the children narrated the first story that had not been taught at school before. Previous studies (Griessler, 2001; Kellerman, 2001) indicated that L3 learners used both L1 and L2 while speaking their L3. Our study showed that most of our learners used their L1 while transfer lapses occurred. However, it is difficult to explain the prevalence of $L 1$ and not of $L 2$ in the case of transfer lapses, since most research studies point out that $L 2$ is the main source of transfer lapses while one is speaking in his/her L3. (Hammarberg, 2001; Dewaele, 1998; Ringbom, 1987).

Code switching serves as a tool that facilitates interaction. It helps individuals to overcome communication obstacles in one or several of their languages. The choice of L1 as the main source of transfer in L3 production might have to do with individual factors such as character of the interlocutor, age of the subjects, anxiety or characteristics of the languages involved.

During interaction with the interlocutor our learners used Greek which was either their L1 or their L2. Bilinguals and multilinguals have been reported to be sensitive to the linguistic context of language use and appear to be "intuitively responsive to the linguistic needs of their interlocutors. We see this heightened sensitivity as part of the trilingual's overall metalinguistic awareness and language competence" (Hoffmann \& Stavans, 2007, p. 58). Also, Andreou (2007) points out that the experience of three languages is likely to result in enhanced awareness of the analysis and control components of language processing on the part of trilinguals.

The preference for using two rather than three languages at a time can be partially explained with reference to context, preference, and experience. However, it cannot be fully explained in cognitive terms. According to Hoffmann \& Stavans (2007), more data from more diverse sociolinguistic contexts might be able to explain if trilinguals tend to switch in a bidirectional manner and if this is something that indicates their trilingual competence.

The most interesting part of our findings is the fact that our first group whose L1 was Albanian had this language sequence when they code switched while using their L3 in "story 1" (the one that was new to them):

$$
\text { - L3 } \rightarrow \text { L1 (Albanian) } \rightarrow \text { L2 (Greek). }
$$

According to Jessner (2008), it has been observed that L2 in a trilingual system takes up a specific role: $L 3$ learners or users do not rely on their L1 as one would expect, but mainly on their L2, which serves as the "bridge language". 
In our study the children were speaking in their $L 3$ and when they felt that they needed help they used their L1 and then they continued speaking in their L2. There is not a safe explanation for this finding on our behalf that can be given just yet. We believe that when we reach a larger sample we will be able to confirm this finding and hopefully propose some reasoning. However, factors that could possibly affect cross-linguistic influence have been suggested by researchers. One of them may be "recency" according to Hammaberg (2001). He proposes that it could be hypothesized that learners are more likely to borrow from a language they actively use than from other languages they may know but they do not use as often. Another factor is the "foreign language effect" or "L2 status" (Meisel, 1983; Cenoz, 2001; Hammaberg, 2001), which is the tendency of $L 3$ learners or users to activate their first foreign language they have acquired or learnt. Also, several studies have indicated that learners appear to have a pattern of using the L2 or languages other than their L1 as the source language of cross-linguistic influence (Clyne, 1997; Williams \& Hammaberg, 1997; De Angelis \& Selinker, 2001).

We hope that our research on trilingualism/ multilingualism regarding this combination of languages (Greek, Albanian and English) will give more data on the way these specific languages interact. More specifically, we hope to provide some insight on these speakers' language choice and how they automatically choose how they code switch each time they need to.

Table 1.

Number of transfer lapses from L1 per group in the two stories

\begin{tabular}{|l|c|c|c|c|}
\hline & \multicolumn{2}{|c|}{ Group 1 (L1 Albanian) } & \multicolumn{2}{c|}{ Group 2 (L1 Greek) } \\
\hline & $\begin{array}{c}\text { Total Number } \\
\text { of Utterances }\end{array}$ & Lapses & $\begin{array}{c}\text { Total Number } \\
\text { of Utterances }\end{array}$ & Lapses \\
\hline Story 1 & 638 & 124 & 285 & 114 \\
\hline Story 2 & 459 & 319 & 158 & 97 \\
\hline
\end{tabular}




\section{References}

Andreou, G. 2007. Phonological awareness in bilingual and trilingual schoolchildren. The Linguistics Journal, 3 (3), 8-15.

Baetens-Beardsmore, H. (ed.) 1993. European models of bilingual education. Clevedon: Multilingual Matters.

Cenoz, J. 2001. The effect of linguistic distance, L2 status and age on crosslinguistic influence in L3 acquisition. In J. Cenoz, B. Hufeisen and U. Jessner (eds.), Cross-linguistic Influence in Third Language Acquisition: Psycholinguistic Perspectives, 8-20. Clevedon: Multilingual Matters.

Cenoz, J. and Genesee, F. 1998. Psycholinguistic perspectives on multilingualism and multilingual education. In J. Cenoz and F. Genesee (eds), Beyond Bilingualism: Multilingualism and Multilingual Education, 16-32. Clevedon: Multilingual Matters.

Cenoz, J., Hufeisen, B. and Jessner, U. 2001. Looking beyond second language acquisition: Studies in tri- and multilingualism. Tubingen: Stauffenberg Verlag.

Clyne, M. 1997. Some of the things trilinguals do. The international Journal of Bilingualism 1, 95-116.

De Angelis, G. and Selinker, L. 2001. Interlanguage Transfer and competing linguistic systems in the multilingual mind". In J. Cenoz, B. Hufeisen and U. Jessner (eds.), Cross-linguistic Influence in Third Language Acquisition: Psycholinguistic Perspectives, 8-20. Clevedon: Multilingual Matters.

Dewaele, J.-M. 1998. Lexical inventions: L2 versus L3. Applied Linguistics, 19, 471-490. 
Griessler, M. 2001. The effects of third language learning on second language proficiency: An Austrian example. International Journal of Bilingual Education and Bilingualism, 4 (1), 50-60.

Grosjean, F. 2001. The bilingual's language modes. In J. Nichol (ed.), One mind, two languages: Bilingual language processing, 1-22. Oxford: Blackwell.

Hammarberg, B. 2001. Roles of L1 and L2 in L3 production and acquisition. In J. Cenoz, B. Hufeisen and U. Jessner (eds.), Cross-linguistic influence in third language acquisition: Psycholinguistic perspectives, 21-41. Clevedon: Multilingual Matters.

Haugen, E. 1956. Bilingualism in the Americas: A Bibliography and Research Guide. (Publication of the American Dialect Society, No. 26). University of Alabama Press.

Herdina, P. and Jessner, U. 2000. The dynamics of third language acquisition. In J. Cenoz and U. Jessner (eds.), English in Europe: The acquisition of a third language, 84-98. Clevedon: Multilingual Matters.

Hoffmann, C. and Stavans, A. 2007. The evolution of trilingual codeswitching from infancy to school age: The shaping of trilingual competence through dynamic language dominance International Journal of Bilingualism 11, 55-72.

Hufeisen, B. 1998. L3-Stand Der Forschung - Was Bleibt zu tun? In B. Hufeisen and B. Lindemann (eds.), Tertiarsprachen: Theorien, Modelle, Methoden, 169-185. Tubingen: Stauffenburg.

Jessner, U. 1999. Metalinguistic awareness in multilinguals: Cognitive aspects of third language learning. Language Awareness 8, 201-209.

Jessner, U. 2008. Teaching third languages: Findings, trends and challenges. Language Teaching 41:1, 15-56. Cambridge University Press.

Kellerman, E. 2001. New uses for old language: Cross-linguistic influence in the depiction of motion and emotion. In J. Cenoz, B. Hufeisen and U. Jessner (eds.), Cross-linguistic Influence in Third Language Acquisition: Psycholinguistic Perspectives, 170-191. Clevedon: Multilingual Matters.

Lambert, W.E. 1990. Persistent issues in bilingualism. In B. Harley, A. Patrick, J. Cummins and M. Swain (eds.), The development of second language proficiency, 201-218. Cambridge, U.K.: Cambridge University Press. 
Meisel, J. 1983. Transfer as a second language strategy. Language and Communication 3, 11-46.

Oksaar, E. 1983. Multilingualism and multiculturalism from the linguist's point of view. In T. Husén and S. Opper (eds.), Multicultural and multilingual education in immigrant countries, 17-36. Wenner Gren Symposium Series, Vol. 38. Oxford: Pergamon Press.

Ringbom, H. 1987. The role of first language in foreign language acquisition. Clevedon: Multilingual Matters.

Skutnabb-Kangas, T. 1984. Bilingualism or not. Clevedon: Multilingual Matters.

Williams, S. and Hammaberg, B. 1997. L1 and L2 influence in L3 production. Stockholm: Stockholm University, Centre for Research on Bilingualism. 